\title{
Multidisciplinary analysis of a mummified cranium claimed to be that of a medieval execution victim
}

\author{
Martin J. Smith • Paul Kneller • Denise Elliott • \\ Christine Young $\cdot$ Harry Manley $\cdot$ David Osselton
}

Received: 17 June 2011 / Accepted: 28 September 2011

(C) Springer-Verlag 2011

\begin{abstract}
This article presents a multidisciplinary analysis of a human skull with preserved soft tissue curated by a small museum in Boscastle, Cornwall, UK. The skull lacks a mandible and is coated in a black tar-like substance. Records left by a previous museum curator (now deceased) claimed the skull to be the head of a medieval execution victim. The skull was purportedly recovered from a London church that was destroyed during the Second World War where it had been kept in a carved oak box. If these details are correct, the skull would appear to have been venerated as a relic. The skull and box have been analysed using a range of techniques including computerised tomography, laser scanning, microscopy, infrared spectroscopy and radiocarbon dating. These analyses demonstrated the skull in fact to be that of an Egyptian mummy dating from the Ptolemaic period. Other instances have been noted of parts of Egyptian mummies being presented as European saintly relics, and the 'Boscastle skull' would appear to be an example of such. A wider point illustrated by the work presented here is that sufficient application of modern analytical techniques may reveal considerable information regarding human remains which otherwise have little or no provenance. This point strengthens arguments for the retention of such remains by curating institutions.
\end{abstract}

M. J. Smith $(\bowtie) \cdot$ P. Kneller $\cdot$ H. Manley $\cdot$ D. Osselton School of Applied Sciences, Bournemouth University, Poole, Dorset BH12 5BB, UK

e-mail: mjsmith@bournemouth.ac.uk

D. Elliott $\cdot$ C. Young

CT/MRI Department, Radiology,

Poole Hospital NHS Foundation Trust,

Longfleet Road,

Poole, Dorset BH15 2JB, UK
Keywords Provenance $\cdot$ Mummy $\cdot$ Relic $\cdot$ Computerised tomography . Fourier transform infrared spectroscopy. FTIR $\cdot$ Resin

\section{Introduction}

Archaeological human remains with preserved soft tissue are rare in Northwest Europe. Where such remains survive, they are generally the product of specific and unusual circumstances regarding their postmortem treatment or depositional context. In this paper, we present analyses and discussion of a human cranium with a degree of preserved soft tissue, previously alleged to be of medieval or Early Modern date, curated by a small UK museum. The Museum of Witchcraft in Boscastle, Cornwall, in southwestern England houses a wide range of material with perceived links to occult practices or with historical or cultural significance as regards the ways that witcheraft has been perceived by society in general during recent centuries. The museum was founded in 1951, with much of the current collection having been assembled by its founder Cecil Williamson (1906-1996). For many items within the collection, little information is available regarding provenance with what is known deriving from notes and display cards provided by Williamson for which no additional corroboration is available.

The collection contains a small quantity of human skeletal remains, mainly skulls. Examination of these by the first author revealed nothing to suggest that any of these were of great antiquity, with a likely origin in recent (nineteenth to twentieth century) anatomical collections. One cranium, the subject of the current article, stands out from these other remains in several respects. In addition to the aforementioned soft tissue preservation, much of this 
skull (accession no. 343) is covered with a viscous dark material resembling tar or bitumen. The posterior portion of the skull is overlain by multiple layers of cloth which are similarly covered and interleaved with the tar-like substance. The skull is associated with a rectangular wooden box in which it was purportedly kept prior to its acquisition by the museum.

The accession record and display card, written by Williamson, imply the skull and box to date from the medieval or possibly Early Modern periods. After introducing the skull, these read as follows:

...those in authority decided in their self-assumed wisdom to chop his head off and dump it into a cauldron of hot tar, and the head was exposed as a public warning. At some later date a kind soul, almost certainly a priest, retrieved the much abused head and placed it in this bible-box. Hitler's bombs blasted the London church where the box was found in the rubble of what had been the east wall directly behind the altar. Rejected by the church as an unwanted relic, the head passed through numerous hands...

(Williamson, undated)

Neither skull nor box had been subject to any scientific investigation since being acquired by the museum. The current curators kindly agreed to loan both items for analysis by the present authors in 2009-2010, with a view to establishing the possible date and provenance of the skull, the reasons for the soft tissue preservation and the potential veracity of its purported link with the box.

\section{An uncommon survival?}

As shown in Fig. 1, the extent of soft tissue preservation is varied across the skull. The mid-facial region and palate exhibit no preserved soft tissue, whereas the soft tissue structures within the orbits are largely intact. As noted in other cases of natural and artificial preservation (Lynnerup 2007), the eyes survive in a flattened form due to the loss of vitreous humour. The skin of the eyelids is present, although no skin remains over the muscles surrounding the eyes (orbicularis oculi). Above the orbits, the skin of the scalp is still present, but with some flaking in areas revealing the frontal bone beneath. Parts of the scalp surviving more laterally and posteriorly retain hair, which had been closely shaved, being only 1-2 mm long (Fig. 1b). All the hair visible was a pale beige/orange colour consistent with a loss of pigmentation, as is common in archaeological specimens with preserved hair. Such loss of melanin from hair is often seen in European bog bodies (Wilson et al. 2001). The mandible is absent and no vertebrae or other structures of the neck are present.
The tar-like substance exhibited variable preservation. Over the upper portions of the skull, this material was less well preserved, being dry and friable with a matt quality in the light. On the more inferior portions and particularly the base of the skull, this substance was generally smoother and more solid. The material coating the basal area was also shinier and reflective. On attempting to section samples of bone from this region, heat created by the cutting wheel used caused this material to begin to liquefy, becoming viscous and aromatic. Around the occipital region where this dark substance was interleaved with fabric, it was apparent that additional layers of cloth had originally been present, indicated by impressions of the weave visible in the tar-like material (Fig. 1d).

The box was made of unjointed oak boards held together with handmade iron nails. Each plank was $\sim 19 \mathrm{~mm}$ thick, together forming an irregular rectangular box with the following dimensions: lid and base panels, $372 \times 338 \mathrm{~mm}$; front and rear panels, $340 \times 185 \mathrm{~mm}$; side panels, $262 \times$ $176 \mathrm{~mm}$. The lid was attached with leather straps. These were replacements for earlier straps, remnants of which could be seen beneath the present versions. The four side panels and lid were covered with crudely carved imagery. These images lack detail and are effected in a naive style that renders interpretation somewhat difficult. The lid, front and side panels depict what appear to be communion scenes involving figures that exhibit aspects of dress that might place them in the sixteenth or early seventeenth century (Fig. 2). The final panel at the rear of the box is a human mask flanked by foliate motifs in place of ears and would seem a fairly standard 'green man' image, as is common in carvings found in English churches (Raglan 1939; Centerwall 1997). Multiple linear defects were present on the underside of the box running parallel to its anterior-posterior axis. These suggested the box to have been kept on a hard, possibly stone, surface, or perhaps in a niche, and repeatedly dragged forwards and backwards. Such movement might be consistent with Williamson's story of the box having resided in a church where it was periodically drawn forwards to access the 'relic' within.

\section{Initial thoughts}

Prior to detailed analysis, a range of possibilities occurred to the present authors regarding the possible date and provenance of the skull. Certainly there are examples of heads and other body parts of executed individuals surviving to modern times, either as holy relics or simply curiosities. Prominent examples include the head of Oliver Plunkett, Archbishop of Armagh who was executed in 1681 (Fig. 3a). Parts of Plunkett's body including his head were recovered by his supporters and continue to be venerated as relics, now in St. Peter's Church, Drogheda, following 
Fig. 1 a Frontal view of skull with droplets of tar-like material visible at lower margins of left orbit and nasal cavity (arrowed). b Inset showing scalp with shaved hair visible. c Lateral view of skull showing cloth wrapping at sides and back of cranium. d Inset of fabric showing the weave pattern of further layers of textile impressed into the tar-like substance coating the cloth wrapping

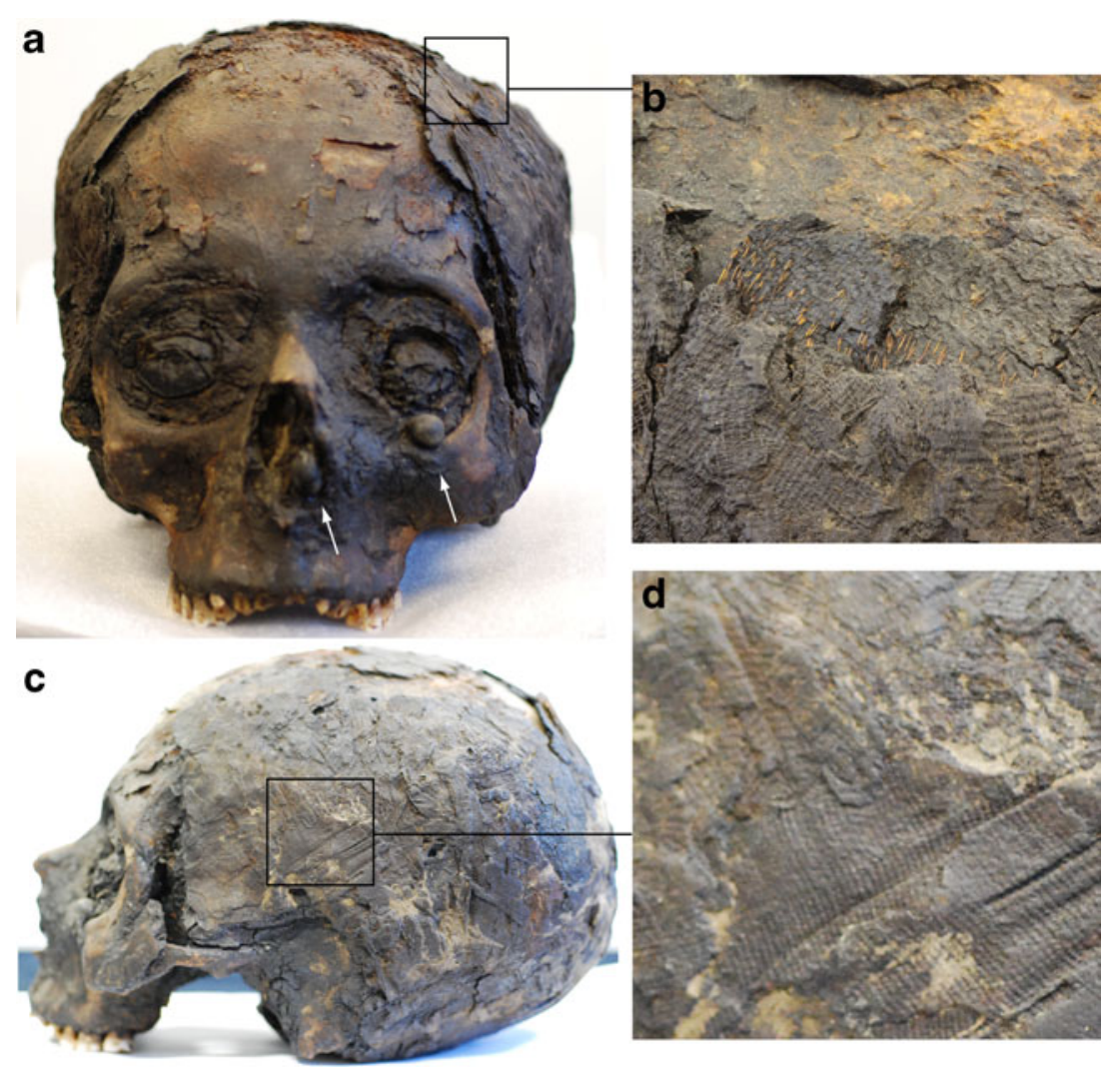

Plunkett's canonization in 1975 (Kilfeather 2002). The shaved hair of the Boscastle head might relate to wig wearing, which would be consistent with an individual from the time of Plunkett; alternatively, at times, those condemned to public punishment would have their heads shaved (L'Engle 2002). Equally well known is the head with preserved soft tissue formerly known as the 'Wilkinson head' (Fig. 3b), long purported to be the head of Oliver Cromwell (1599-1658). This claim was upheld by an extremely thorough analysis conducted by two anthropologists, Pearson and Morant (1934). The 'Wilkinson head' has since been reburied in Cromwell's old college at Cambridge. Following the restoration of the monarchy in 1660 , Cromwell's body, along with those of two others indicted for the regicide of Charles I, was exhumed and symbolically 'executed' by hanging. The regicides' heads were then severed and displayed on poles above Westminster Hall, where Cromwell's head is known to have remained for 20 years. Having previously been given a state funeral, Cromwell's body is known to have been embalmed, which may explain the head's survival in a well-preserved state for such a long period, although it has been speculated that it might also have been dipped in some form of tar prior to display (Tarlow 2008). A further example of the survival of desecrated remains of discredited rulers has been highlighted by the recent analysis of a head with mummified soft tissue from France (Fig. 3c). After a multidisciplinary investigation,
Charlier et al. (2010a, b) established the cranium in question to be that of King Henri IV (1553-1610). The head was removed from its resting place along with those of other former monarchs by revolutionaries in 1793 (Charlier et al. 2010a, b). Whilst the current article was in preparation, a skull kept within an ornate box, claimed to be the head of St. Vitalis of Assisi (1295-1370), was sold at auction in County Meath, Ireland (BBC News online 2011). Finally, John Strype 's Survey of London (1720) cites an account of the discovery of the heads of four Catholic martyrs in the cellar of a convent in Blackfriars, following the Great Fire of London (1666). This story has further parallels with the professed provenance of the Boscastle skull in that each had been kept in its own lidded container (in this case made of pewter) with a "substance of a blackish colour...crumbled to dust at the bottom" (Strype 1720). The practice of tarring body parts of executed criminals for public display is likely to have been common as this was one of the few methods available in Medieval and Early Modern Europe to ensure the preservation of soft tissues. After the trials that followed the Monmouth rebellion of 1685 where allegedly several hundred individuals were hung, drawn and quartered (opinions vary regarding the precise number), the tarring of heads and quarters is recorded to have taken place on an almost industrial scale (Abbott 2000). A further example of the use of tar-like substances in the medieval period can be seen on the shroud of the St. Bees Man. This fourteenth 
Fig. 2 Views of the wooden box purported to have been used as a container for the skull. a View of apparent communion or similar scene on the right side of box. b 'Green man' image carved on rear face of box. c Three-dimensional laser scan reconstruction. $\mathbf{d}-\mathbf{h}$ Carvings on the lid, front, rear, left and right sides of the box, respectivelydrawings transcribed from laser scan data
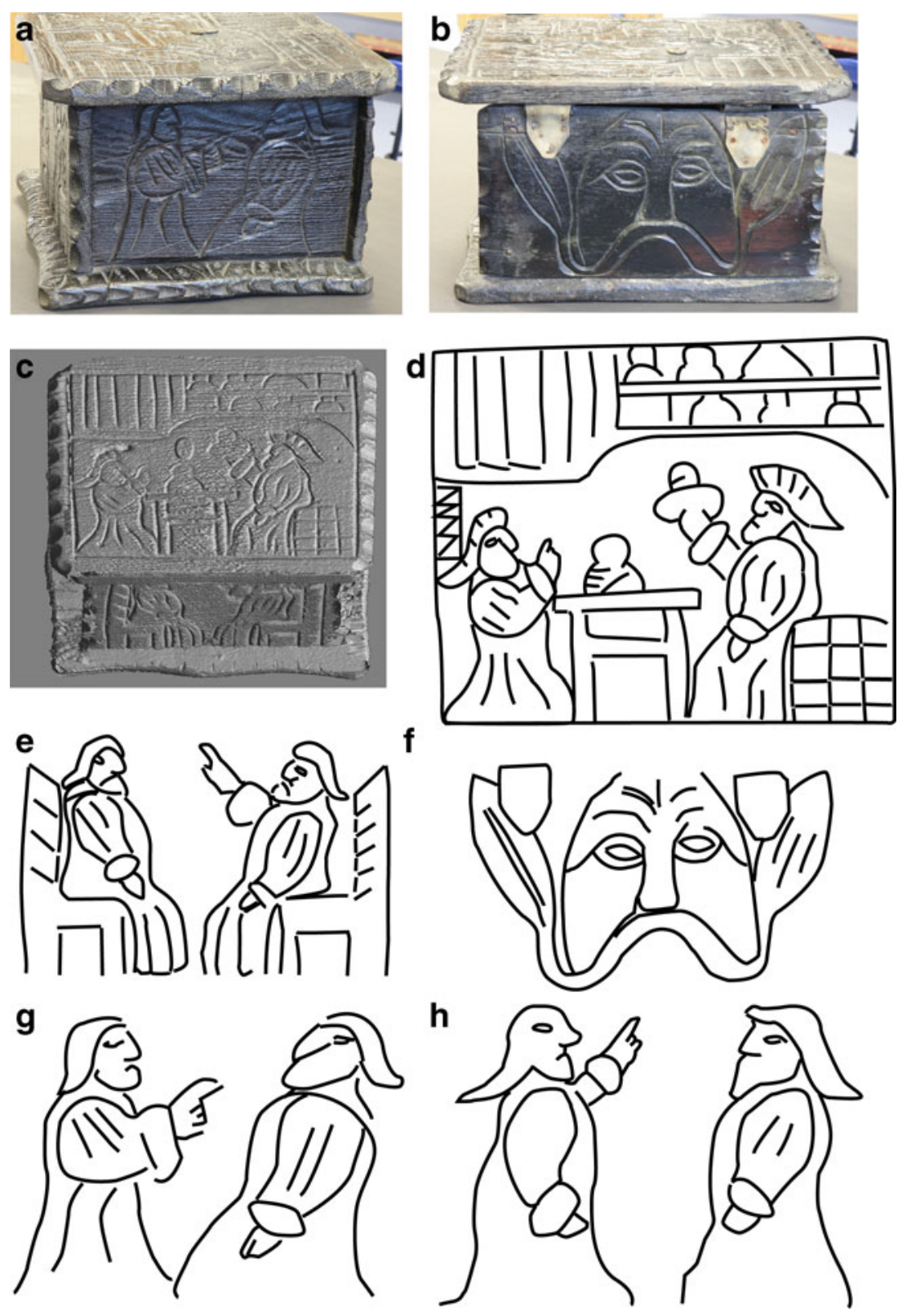

century individual, one of the best preserved archaeological bodies ever discovered, was covered with a cloth wrapping coated with a resinous substance identified by gas chromatography as pine pitch (Knüsel et al. 2010).

Whilst the above points demonstrate the origin of the Boscastle skull as told by Williamson to be plausible, at least on first appearances, other possibilities were also considered. One such prospect entertained by the present authors was that the skull might be that of a relatively recent embalmed body as has been noted in the case of a number of nineteenth and early twentieth century US 'sideshow mummies' that have been subjected to more recent analysis (Conlogue et al. 2008). Such 'mummies' have commonly been imbued with famous or dramatic identities generally aimed at maximising levels of interest and the consequent profits they would generate.

A third possibility considered was that the Boscastle skull might be that of an Egyptian mummy. Certainly the presence of cloth wrappings at the rear could indicate an unwrapped mummy, although several other features led the present authors initially to regard this possibility as less likely. The differential nature of the soft tissue preservation coupled with the thick and ubiquitous nature of the black coating seemed to suggest against careful preservation by an experienced embalmer. The lack of ocular prostheses was a further, albeit circumstantial, negative indicator. Lastly, the fact that the tar-like material thickly covered the foramen magnum (Fig. 4b) showed that it had been 
Fig. 3 Other preserved heads from northern Europe. a The head of St. Oliver Plunkett, Bishop of Armagh, executed 1681. b The 'Wilkinson head' identified as Oliver Cromwell (Pearson and Morant 1934). c The head of Henri IV of France (Charlier et al. 2010a)
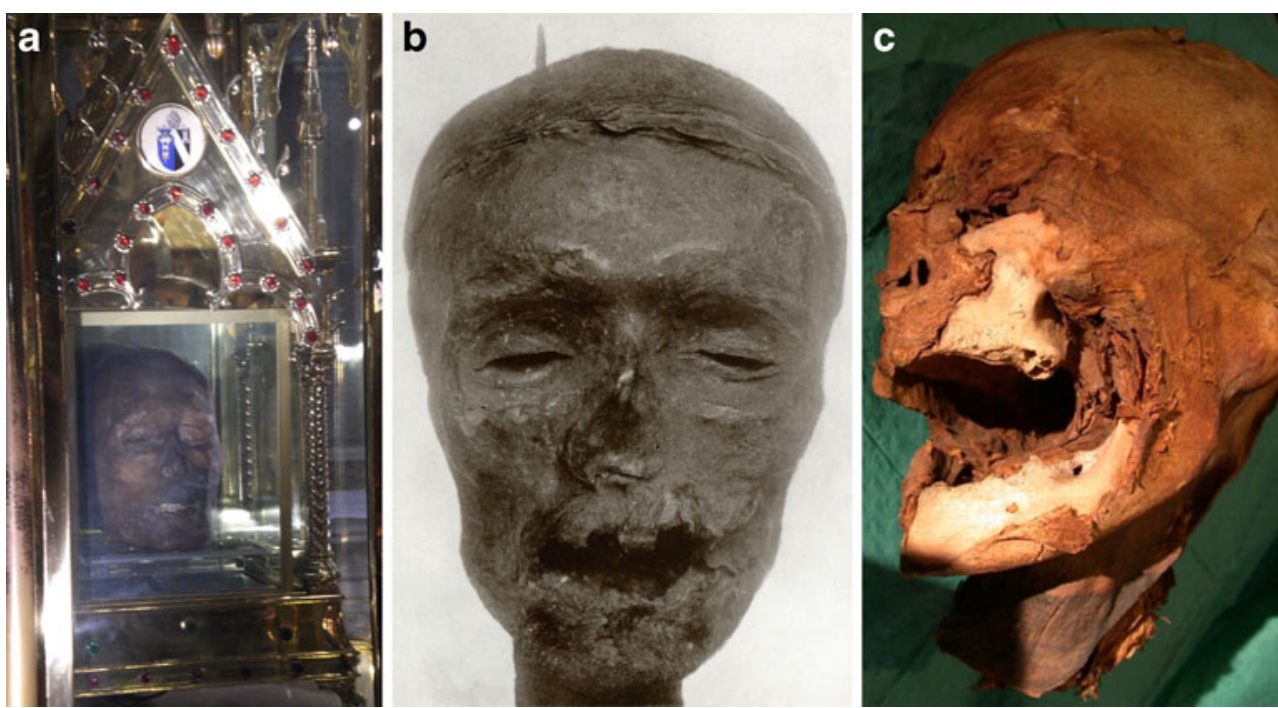

applied once the head had been separated from the body. This evidence for decapitation in some form would seem consistent with the claim cited by Williamson that the individual had been executed and subsequently tarred to preserve it for display whilst ostensibly suggesting against the skull having an ancient Egyptian origin.

\section{Modern analyses}

Recent years have seen growing acknowledgement that human remains with preserved soft tissue are best investigated by a multidisciplinary team of specialists (Lynnerup 2007). Such an approach was taken with the Boscastle skull
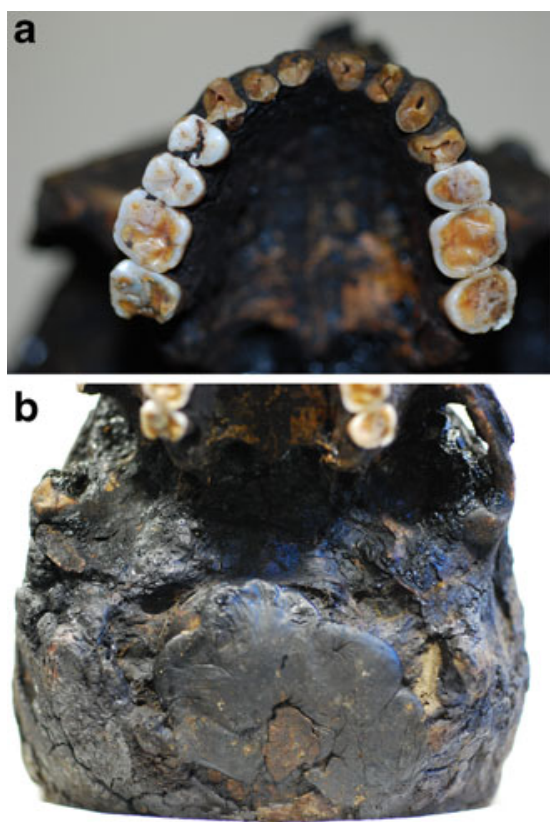

Fig. 4 Inferior views of skull showing dentition (a) and tar-like material covering the skull base and foramen magnum (b) and a range of different analytical techniques were applied by the present authors. Firstly, a standard physical anthropological analysis was carried out in order to determine a demographic profile for the skull. Sex was assessed using the cranial features given by Acsádi and Nemeskéri (1970) and Buikstra and Ubelaker (1994). Assessing age at death using only the skull is a fairly inexact endeavour in adult individuals, with sutural fusion and dental wear likely to be the principal available indicators, neither of which is particularly precise. In the case of the Boscastle skull, the cranial sutures were obscured. Age was assessed using the dental wear stages devised by Miles (2001) and also Brothwell (1994). Ancestral affinity was assessed morphologically according to the expression of craniofacial traits summarised by Gill (1998).

The morphology of the skull and the extent of soft tissue preservation were then further investigated using computerised tomography (CT). A General Electric (GE) VCT Lightspeed 64 slice CT scanner was used to scan the skull. The skull was positioned on the CT scan table, resting on its base, median sagittal plane vertical. The CT scanner was centred on the head and a lateral topogram scan initiated, which scanned from the most anterior point to the most posterior point. From this topogram, the scan was planned. The CT images were acquired in the coronal plane, at a $0.625-\mathrm{mm}$ slice thickness, using a soft tissue algorithm (window width $(W), 100$; window length $(L), 40)$. These data were also reconstructed automatically on a bone algorithm (W2000, L500) at $0.625-\mathrm{mm}$ slice thickness. The bone windows data were then loaded into a GE volume rendering reconstruction software package. Using this software, a series of 3D movies showing various views of the skull was made. These videos have been submitted as supplementary material for online viewing. The data (in DICOM format) and reconstructed images were burnt onto compact discs for archiving using GE Centricity DICOM 
viewer 2.1. The skull was also scanned by magnetic resonance imaging (MRI), although this proved unsuccessful, indicating a lack of unbound hydrogen protons consistent with a very dehydrated sample.

Samples of the tar-like substance coating the skull were analysed by Fourier transform infrared spectroscopy (FTIR). A Varian Scimitar 800 FTIR was used with a Specac Golden Gate diamond ATR sample head. A 20 scan sample and background protocol was run together with the ATR correction setting on the instrument. The black substance was considered most likely to be some form of hydrocarbon composite such as either naturally occurring geological tar (bitumen) or some form of pitch derived from wood. Samples of commercial bitumen and pine sap were prepared and sampled for use as known comparators in the FTIR analysis in order to assess whether the substance coating the skull belonged to the same or a similar class of material as either of these. The bitumen was dissolved in dichloromethane and evaporated to dryness to remove gritty particles; pine saps were either solid or viscous samples from known sources of untreated timber. The substance coating the skull was differentially preserved. Over the cranium, this material was dry, cracked and friable, whilst at the base of the skull, particularly at the spheno-occipital portion, the tar-like substance was shiny and smooth. Multiple samples from different locations on the skull were analysed in order to compare differently preserved portions

When radiocarbon dating skulls, it is common to cut a 'window' of bone from the cranial vault, thus avoiding the facial skeleton. Given the unusual standard of preservation, such a practice was felt to be undesirable as this might risk compromising any further soft tissue preserved within the cranium due to the airtight seal formed by the tar-like substance. An attempt was made to sample bone from the hard palate, but this proved untenable due to the small size of the sample obtained, which was below the threshold needed for accelerator mass spectrometry (AMS) dating. Instead, a loose fragment of the fabric adhering to the back of the skull was sent for AMS dating following microscopic examination. This sample was prepared and analyzed at the Waikato Radiocarbon facility (New Zealand) following routine AMS protocols whereby potential contaminants were removed by solvent extraction (xylene, toluene, ether, acetone and distilled water in an elutrope sequence) followed by a series of dilute $\mathrm{HCl}, \mathrm{NaOH}$ and $\mathrm{HCl}$ washes.

Finally, the box was examined by an expert in archaeological wood (Richard Harris) and was also scanned using a Konica Minolta VI900 Laser Scanner in order to produce a $3 \mathrm{D}$ record of its form and the carvings with which it was covered. The VI900 is a 'point-and-shoot' style laser scanner with a triangulation light block method of measurement and a field of view of approximately
$0.5 \times 0.4 \mathrm{~m}$. A total of 18 individual scan 'point clouds' were collected with a distance of approximately $0.7 \mathrm{~m}$ between the laser source and the box surface. Each scan had a laser point separation of $\sim 0.5 \mathrm{~mm}$ and a point accuracy of $\pm 0.05 \mathrm{~mm}$. The individual point's clouds were rendered to create a mesh representing the 3D surface of the box. Overlapping points in adjacent scans were then used to create a composite 3D object, which could be rotated and inverted for study. A major advantage of using 3D data to analyse the box was the ability to move a theoretical light source across the box surface. This created a shadow effect which enhanced the visualisation of the shallow carvings (Fig. 2c).

\section{Results}

\section{Demographic data}

Most of the principal sexually dimorphic characteristics of the skull were directly visible. The skull exhibited no male expressions of traits with glabellae and mastoid processes consistent in form with a female individual. The occipital region (examined on CT imaging) also exhibited a 'female' form lacking robust or rugose muscle attachments with a small nuchal crest. It is reasonable to conclude that the individual was most probably female, although the possibility remains that the skull could be that of a gracile male. In so far as they have value in age determination, the cranial sutures were not visible. The basio-occipital synchondrosis was discerned as fused from the midsagittal CT slices. The only other accessible indicator of age at death was the dentition. All permanent teeth were fully erupted, with the exception of the third molars. These teeth normally erupt between the ages of 17 and 21 . However, the degree of wear apparent on the remaining teeth (Fig. 4a) was inconsistent with such a young age, indicating that the third molars had simply never formed (molar agenesis). This observation was later confirmed on CT analysis. Several of the anterior teeth were broken (Fig. 4a), suggesting the skull had fallen onto a hard surface at some time. On the remaining teeth, no carious lesions were recorded, whilst varying levels of wear were apparent. The molars displayed considerable dentine exposure, although this was more pronounced on the left side, indicating an asymmetrical pattern of mastication. Overall, the level of wear present was most consistent with the latter half of Brothwell's (1994) stage II (25-35 years), although this attribution may need to be modified in light of other results obtained as Brothwell's system was developed specifically for British samples and populations from elsewhere may have been subject to greater levels of dietrelated tooth abrasion. 
As regards ancestry, the mid-facial region exhibited features generally consistent with Caucasoid origin, including a relatively narrow nasal aperture, a prominent nasal spine, a parabolic palate and a lack of mid-facial or alveolar prognathism. Such features are consistent with a broad range of Old World populations stretching from India to Ireland and Norway to North Africa (Gill 1998). Congenital absence of third molars has a genetic basis and has been found to vary dramatically in prevalence between populations (Rozkovcová et al. 1999). However, in light of other results obtained during the current study (below), it is of interest that molar agenesis has previously been noted to be particularly common amongst Ancient Egyptian and Nubian populations (Keita 1993; Ruffer 1920). This anomaly is also more common in females (Hillson 1996). Conclusions drawn from morphological analysis of a disarticulated cranium are necessarily broad. Metric analysis of linear measurements using discriminant function software such as CRANID could potentially narrow this conclusion to a more specific ancestral group/geographical region, as demonstrated by Hughes et al. (2005). Such analysis is currently underway and is intended for presentation in a subsequent publication.

\section{Noninvasive imaging}

CT scanning has repeatedly been used to obtain information on techniques of cranial evisceration and materials placed within the body during mummification (Gerloni et al. 2009; Lynnerup 2007). In this case, much of the soft tissue present was difficult to distinguish from the tar-like substance and associated wrappings, although 3D reconstruction using the CT data facilitated the interpretation of soft tissue structures by making them more easily recognizable morphologically. In this regard, the contents of the cranial cavity were of particular interest as this area offered the possibility for discerning whether there were signs of deliberate mummification, particularly in the form of the removal of brain tissue (excerebration), as opposed to the simple coating of the head in tar for display following execution as claimed by Williamson. Initially, it seemed likely that no excerebration had taken place. The meninges were well preserved and the falx cerebri was visible and largely intact. In particular, the persistence of the falx seemed inconsistent with mechanical excerebration as it seemed unlikely that this membrane would survive such an operation largely undamaged. A body of medium density material located at the posterior portion of the cranial cavity (Fig. 5) was thought possibly to comprise atrophied brain matter, similar to preserved brain tissue recently noted in an Iron Age skull from Heslington, Yorkshire, UK (O'Connor et al. 2011). A quantity of shrunken brain matter was similarly preserved within the skull of Henri IV (Charlier et al. 2010a, b). Coupled with the lack of ocular prostheses and the differential level of soft tissue preservation overall, these features seemed to suggest against the skull having undergone deliberate mummification, as practised in Ancient Egypt.

The identity of the material within the back of the skull and the issue of excerebration were resolved on comparison with CT images of several Egyptian mummies with and without preserved brain material present. As shown in Figs. 5 and 6, the material within the Boscastle skull in fact shows several marked differences from preserved brain tissue. It has a uniform density, devoid of internal structures with a flat meniscus more consistent with a congealed liquid than with complex tissues that have become dessicated. Conversely, the preserved brain matter visible in Fig. 6a exhibits variations in density and remnants of anatomical structure (gyri and sulci) whilst lacking a flat meniscus. Examination of the CT images featuring the interior of the nasal cavity showed that the nasal septum was broken, deviating to the left with further damage to the ethmoid and cartilaginous nasal structures consistent with transnasal/transethmoidal excerebration commonly used in Egyptian mummification, as described by Herodotus 1996 (Histories, II, 86). As the tar-like substance covers the entire skull base and must therefore have been applied following separation of the skull from the body, it is also possible that brain tissue could have been removed through the foramen magnum. The above observations concur with features noted by previous studies of CT data acquired from Egyptian mummies comparing the appearance of preserved brain tissue with fabric packing and solidified resin in cranial cavities (Marx and D'Auria Haney 1986; Hughes 1996; Hoffman and Hudgins 2002; Jansen et al. 2002; Boyer et al. 2003; Kieser et al. 2004; Nelson et al. 2007). Similar observations regarding the appearance of resin as opposed to preserved cerebral tissue have also been made by Wade and Nelson (personal communication). Taken together, the features noted within the Boscastle skull (excerebration, breakage of the ethmoid and the introduction of resin into the cranial cavity) are argued to conclusively signify the skull to be that of an ancient Egyptian mummy rather than an executed European from more recent times.

Whilst the mandible was absent, the CT images showed that the mandibular condyles were in fact still present beneath the tar-like material and the temporo-mandibular joints (TMJs) were still intact. Rather than having fallen away naturally, the mandible appears to have been deliberately broken across both rami. The fractured ends are visible, both coated in the tar-like material, indicating that this breakage must have taken place prior to, or during, the embalming process. No pathological lesions were identified during this examination either macroscopically or on the CT imagery. 
Fig. $5 \mathrm{CT}$ images of the Boscastle skull. a-c Threedimensional cut-away reconstructions showing preserved structures and congealed material within the cranial cavity. d Three-dimensional reconstruction of exterior showing similar density of preserved soft tissue and tar-like material. e-g Single-slice images showing profile of cranial contents. Note mandibular condyles visible on image $(\mathrm{g})$
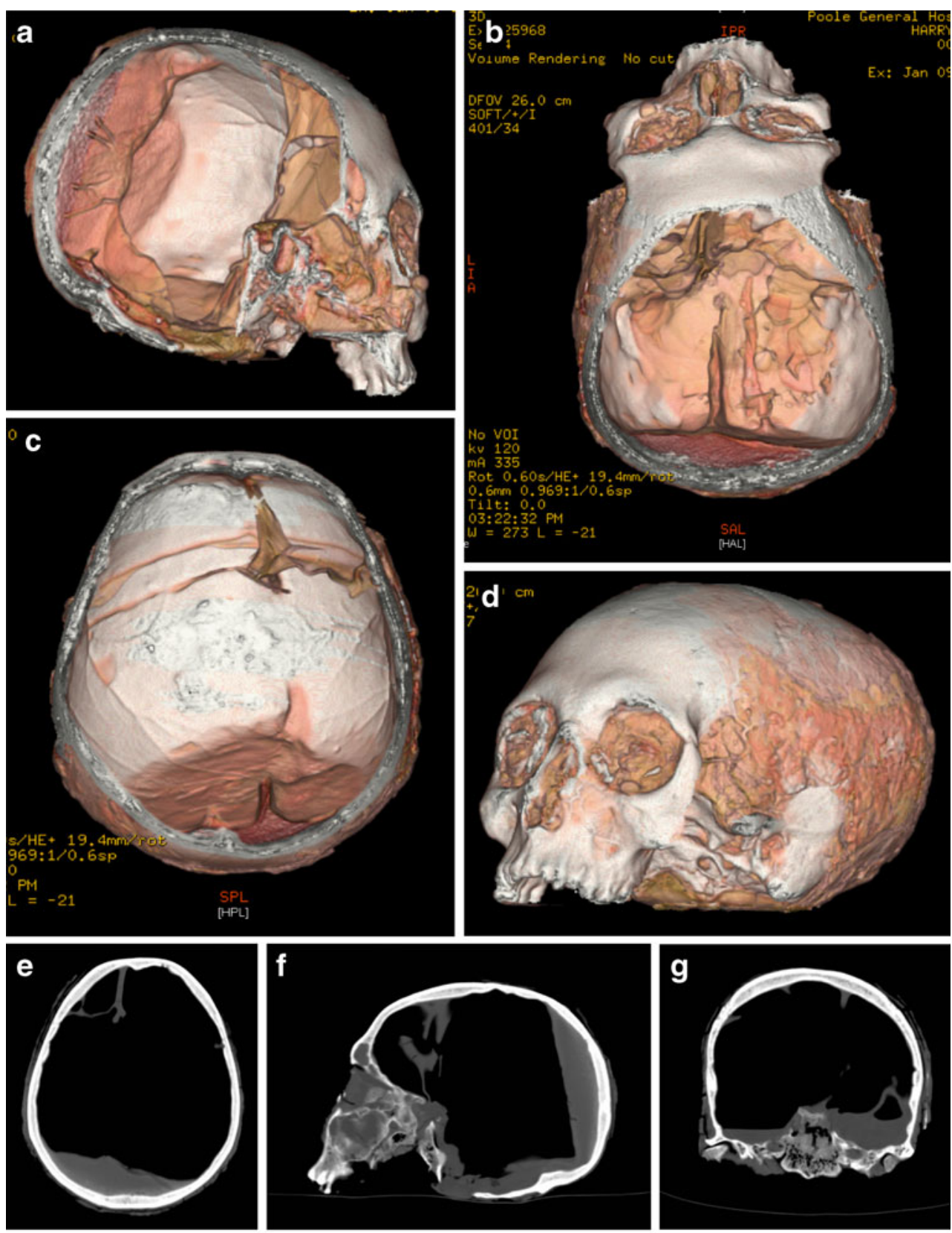

Additional analyses

The results of the FTIR analysis of samples of tar-like material from the skull further corroborated the view that the skull was that of an Egyptian mummy. As shown in Fig. 7, the pattern of peaks obtained from the substance coating the skull bore close similarity to patterns derived from pine sap. Conversely, the distribution of peaks obtained from bitumen was dissimilar in lacking a specific central peak present in all the other spectra obtained. Whilst it was not possible to identify the species, it is reasonable to conclude that the substance contained within and coating the exterior of the skull was some form of wood resin most probably derived from a coniferous tree. This observation accords with other published analyses of preserved organic residues from trees and plants using FTIR (Ribechini et al. 2007; Stern et al. 2008; Charlier et al. 2010a, b). Further investigations to characterise the hydrocarbons and other compounds associated with the skull are ongoing. A further point noted regarding the resin inside the cranial cavity is that two menisci are present, roughly perpendicular to each other, with one in the occipital region and the other 
Fig. 6 CT slices of two Egyptian mummies. a (Hetep-Bastet) with preserved brain tissue present (note differential densities and remnants of structure). b Mummy (known as Lady Hudson) excerebrated mummy with solidified resin present in cranial cavity (images courtesy of A. Wade and A. Nelson)
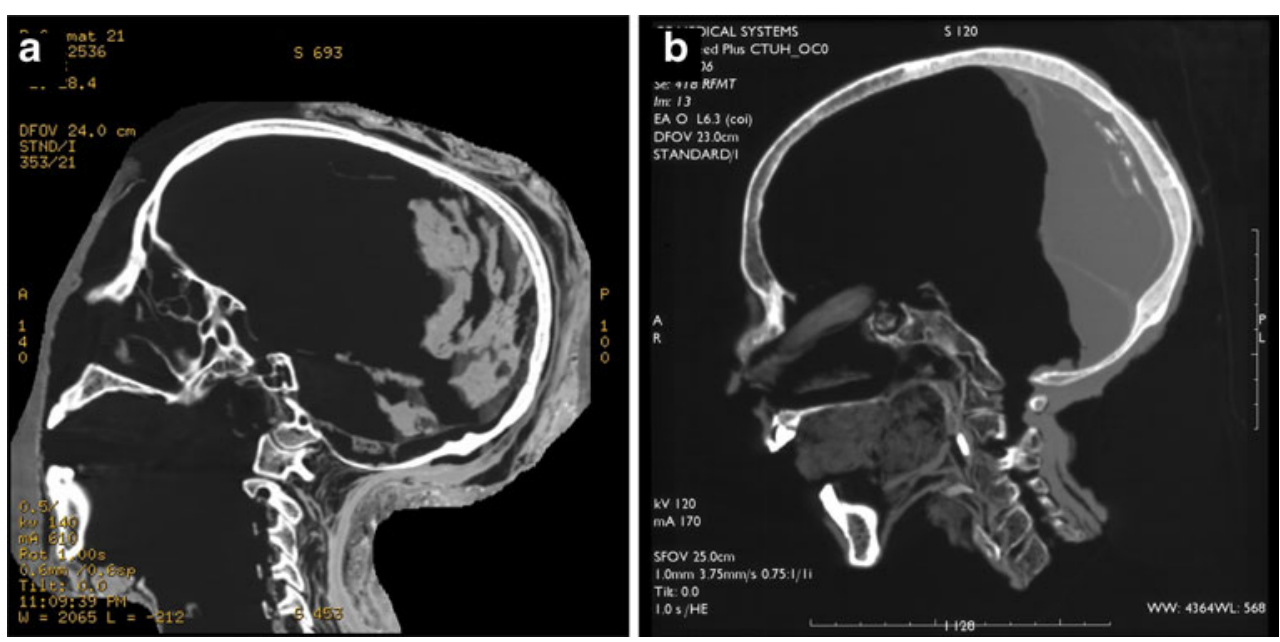

occupying the skull base. This can only have been produced by pouring resin into the skull twice with the body in different positions. During one pour, the body must have been lying supine whilst for the other the body (or perhaps the disembodied head) must have been stood upright. It is not clear from the $\mathrm{CT}$ data which pour preceded the other.

The cloth was a tightly woven linen gauze (Fig. 8). Microscopy of fragments of fabric from the rear of the skull revealed a simple, plain weave (approx. 48 warp and 20 weft yarns per $10 \mathrm{~mm}$ ). This was not diagnostic in itself of any specific style of textile. However, similar plain weaves have repeatedly been noted on mummy wrappings, with only the edges of such fabric generally showing greater variation (Benson et al. 1979; Kieser et al. 2004). The AMS date obtained from the cloth fragment provided conclusive corroboration for the other observations made. The dating result was $2165 \pm 30 \mathrm{BP}$; this calibrates to a range of 360 $170 \mathrm{BC}$ at $68.2 \%$ confidence and $361-112 \mathrm{BC}$ at the $95.4 \%$ confidence interval (OxCal v4.17; Bronk Ramsey 2010). This date range is consistent with an ancient Egyptian mummy, placing the Boscastle skull during the Ptolemaic period. The radiocarbon result also provides support for the interpretation of the black coating over the skull as wood resin rather than bitumen. The presence of the latter would result in the fabric being impregnated with 'old' carbon, causing the radiocarbon result to be inaccurate to a magnitude of at least several millennia. The shaved hair, apparent where portions of the scalp were visible, would be consistent with wig wearing, which occurred throughout Egyptian history. Fletcher (2002) notes that wig wearing was in decline during the Ptolemaic period, although coin images and portraits of the time depict wigs being worn both by Egyptian and other North African elites (Hinks 1928). The mechanism by which the hair had lost its pigmentation, to resemble the hair colour seen in bog bodies, remains unclear and could be considered for any future chemical investigation of the skull.

\section{Discussion}

Taken on its outward appearance, it is easy to see how a story such as that attached to the Boscastle skull might be considered plausible in light of both written sources and surviving documented examples of the heads of execution victims and saintly relics. The application of a range of relatively standard analytical techniques has shown both the origin given by Williamson and the possibility that the skull might be a fairly modern 'fake' to be false. Prior to obtaining the radiocarbon result, indications were already apparent that the skull was not of recent origin. In particular, the degree of dental wear present was incompatible with an individual that had lived in recent times, instead being consistent with diets eaten centuries ago. Furthermore, the lack of success in MRI imaging was informative in itself as this indicated the skull and associated tissues to be thoroughly dehydrated, again inconsistent with a recent date. MRI scanning is not usually successful when applied to mummified tissue without rehydration of the sample (Rühli et al. 2007; Lynnerup 2007). Consequently, the possibility of the skull being part of a relatively recent embalmed body could be discounted.

The CT imaging results exhibit features that are specific to Egyptian mummification practices, whilst the radiocarbon result places the skull at a date that further supports such an interpretation. Egyptian texts give few details regarding procedures used in mummification. The principal reasons for this are likely to be a combination of illiteracy amongst embalmers and perhaps a desire to maintain 'trade secrets'. Conversely, the practical aspects of embalming may simply have been seen as too mundane to merit detailed description in ritual/religious texts which concentrate instead on the magical and religious aspects of mortuary practices. Instead, almost all that is known from written sources on the subject derives from Greek and Roman authors, particularly Diodorous Siculus, Strabo, Pliny the Elder and Herodotus, the latter being commonly 
Fig. 7 FTIR spectra comparing samples of the viscous material covering the skull with potential comparators. The pattern of three double-toothed peaks seen in the dry sample from the top of the skull correlates with a similar, but more pronounced, set of peaks in the sample of dry pine sap analysed. Further similarities are seen between the sample of better preserved coating from the skull base and the sample of fresh pine sap. The trace from the bitumen is dissimilar in that it lacks the central peak present in all the other samples

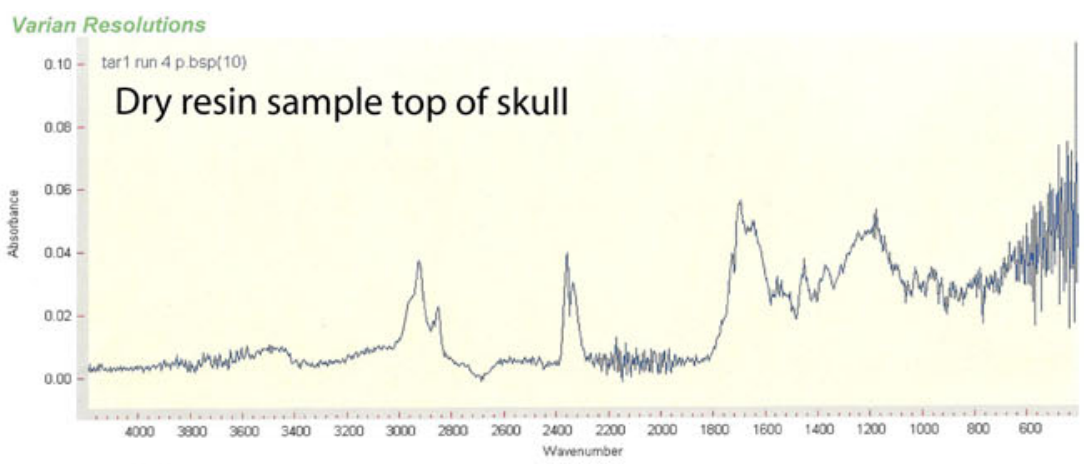

Varian Resolutions

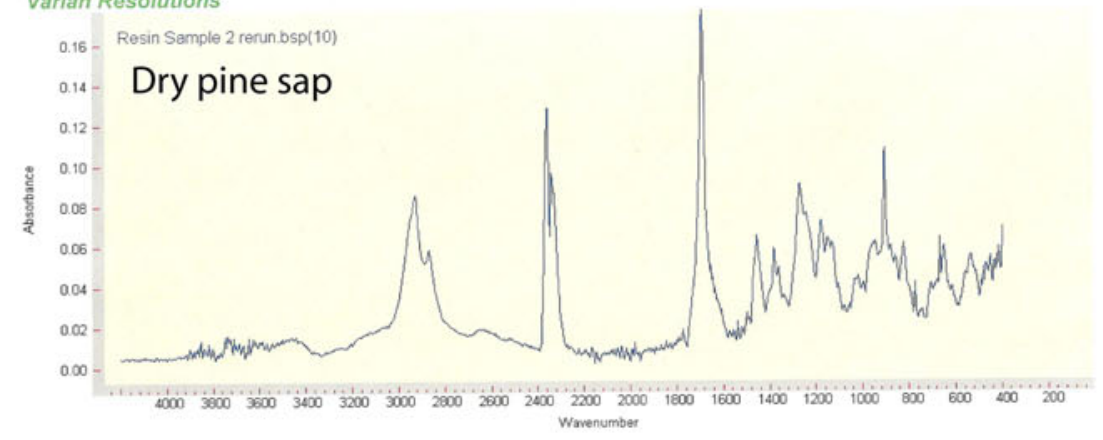

Varian Resolutions

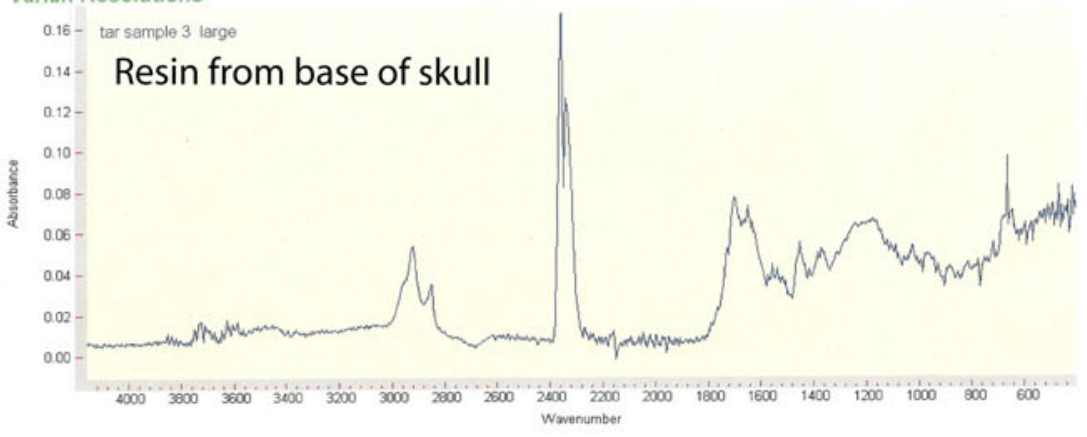

Varian Resolutions
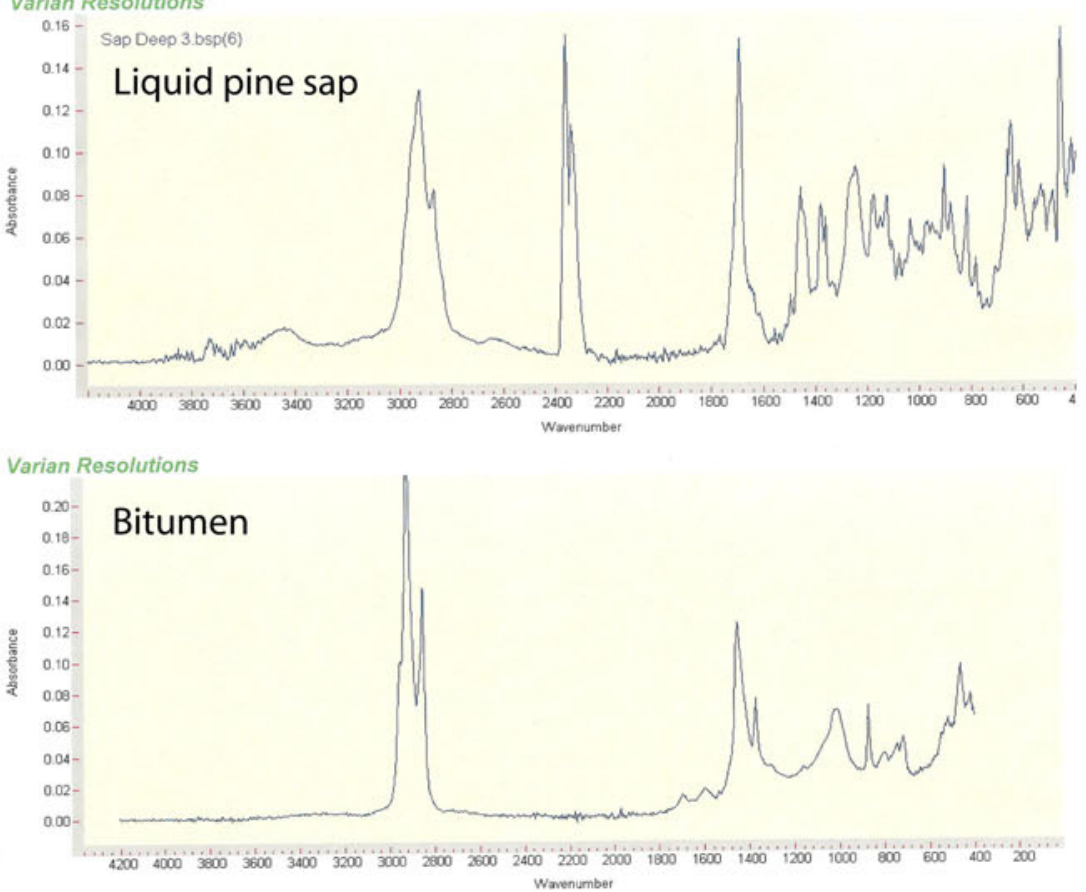
Fig. 8 Fragment of cloth from posterior of skull sent for radiocarbon dating. a Fragment to scale. b Schematic of weave pattern. c, d Optical microscope views
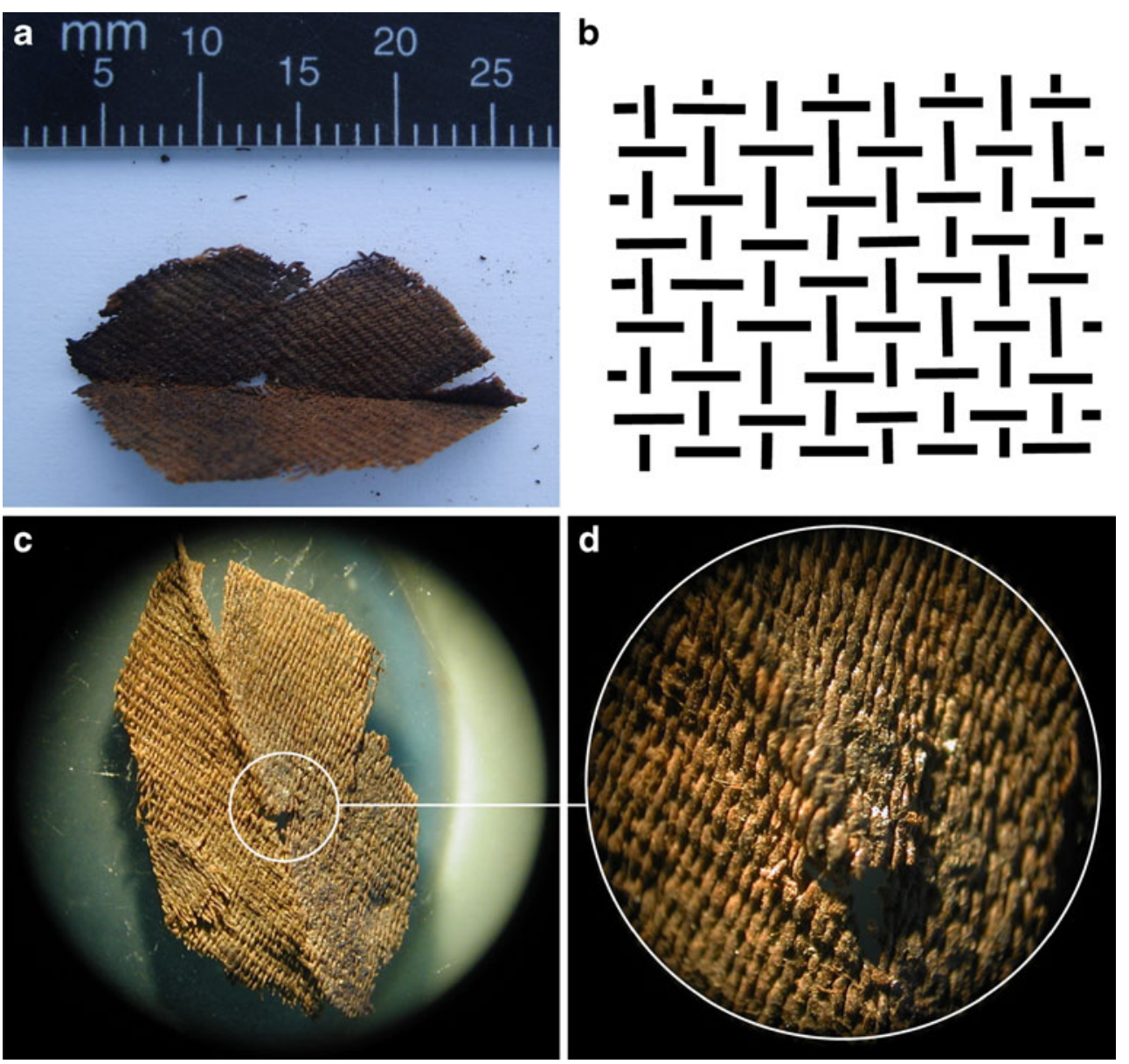

regarded as the most useful to modern researchers. The information provided by such accounts has commonly been taken to constitute a series of observations comprising generalised mummification practices that were typical across a broad geographical and chronological range. Modern mummy studies additionally enjoy the benefits of a growing body of data acquired using non-destructive or minimally destructive analyses that have been applied to increasing numbers of mummies of varying dates (ca. 3300 BC-the early centuries AD). Recent moves towards synthesising such data have led to an increasing realisation that whilst classical sources are not without value, they should be regarded with a degree of scepticism. In particular, Wade and Nelson (2011) have asserted that the views provided in such sources should be viewed as particular to the time and place they were observed rather than be seen as definitive accounts that can be applied generally across the majority of Egyptian mummifications.

Egyptian mummification is generally regarded to have reached its greatest level of sophistication during the XXIst dynasty, ca. 1075-945 BC (Hughes 1996). During later centuries and particularly by the Ptolemaic and Roman periods, standards of mummification are commonly cited to have 'declined' simultaneous to embalming becoming more widely accessible within Egyptian society (Koller et al. 2005). However, it would be more accurate to say that priorities changed, and there was a decreased emphasis on soft tissue preservation in favour of increased attention to overall body form and elaborate external ornamentation (Andrew Wade, personal communication). Nelson et al. (2007) note that the practice of excerebration varies in incidence over time with the decision of whether or not to remove the brain apparently unrelated to wealth or status. Choices regarding this procedure would instead seem to be guided by the opinions of different embalmers as to what constituted best practice. Jansen et al. (2002) illustrate CT images where cerebral membranes including the falx remain visibly intact despite the packing of the cranial cavity with cloth. Marx and D'Auria Haney (1986) note that the falx and dura mater are often observed radiographically to be left intact in mummies of later periods, along with the eyes commonly being left in situ. They further cite relatively poor treatment of the body to be common by the time of Roman occupation in Egypt, with attention shifting instead towards elaborate wrappings and amulets. In this respect, the breakage of the mandible is of further interest. The fact that the mandibular rami were fractured bilaterally whilst the TMJs were intact suggests deliberate breakage 
relatively shortly after death rather than this damage taking place centuries or more afterwards. A possible interpretation might be that the body had been mistreated by grave robbers; however, the fact that the fractured bone ends were coated in resin indicates that this breakage must have taken place around the time of embalming. It should perhaps be considered that this damage may relate to the 'Opening of the Mouth' ceremony in which the deceased was reanimated and given the power of speech for the afterlife, although textual and pictographic evidence for this ceremony imply that it was a largely symbolic procedure (Ikram and Dodson 1998) rather than involving physical opening of the mouth of the deceased, and especially not with the degree of force required to fracture the mandible. Consequently, this aspect of the skull would seem more plausibly interpreted as further evidence of a relatively poor treatment of the body during the later periods when mummification was practised. Whilst falling standards in embalming would seem at least to explain some of the features of the Boscastle skull, another possibility that should be considered in relation to the degree of differential preservation is simply that the deceased may have died some distance away from the embalming workshop. Consequently, by the time the body reached the embalmers, decomposition may already have set in, as has been suggested for the mummy of Pennu which is well wrapped with signs of careful preservation whilst the body was poorly preserved and disarticulated (Marx and D'Auria Haney 1986). An alternative possibility suggested by Andrew Wade (personal communication) is that the second pour of resin might relate to attempts to repair damage following disturbance of the grave in antiquity.

Obviously, a radiocarbon result obtained from associated fabric cannot be regarded as dating the time of death of this individual as accurately as a date obtained on bone from the skull. Instead, this result is indicative of the time when the flax was harvested, with the weaving of the fibres into cloth and its subsequent incorporation in the mummy wrappings being later events. Textiles used in mummy wrappings were not always specifically produced for the purpose, and cloth used for such practices sometimes comprised reused material that had begun life as another item. Examples include reused clothing, sack cloth and even reuse of the sail of a boat (Ikram and Dodson 1998). Such an issue may be particularly relevant in the mummification of less wealthy individuals who may have been less able to afford to have textiles produced specifically for use in mummification, unlike the more exclusively royal and upper class mummies of earlier times. Consequently, the manufacture of the cloth might predate the death of the individual perhaps by decades. A further issue that should be considered with regard to the radiocarbon result relates to observations made by Gove et al. (1997) who obtained a radiocarbon age from the wrappings of a mummified ibis that were at variance by several centuries with a date obtained from the ibis' bone collagen. This discrepancy was suggested to derive from organic deposits produced by microorganisms adherent to the flax fibres that can cause radiocarbon results to appear earlier than the actual age of the sample (Gove et al. 1997). Whilst these caveats clearly raise issues regarding the precision of the date that can be inferred from the AMS result obtained, the broad period at which the Boscastle mummy is likely to have been produced remains unchanged.

The word mummy is commonly believed to derive from a Persian word, mumeia, or mum (Arabic: mumiya), meaning bitumen or pitch. Egyptian mummies are commonly blackened or very dark in appearance due to dessication of the skin, and bitumen was assumed to be an important ingredient in mummification, with the word coming to stand for embalmed bodies (Koller et al. 2005; Lynnerup 2007). In fact, bitumen originating from petroleum appears to have been put to only limited use in mummification (Aufderheide 2003). The FTIR results indicating that the resin from the Boscastle skull is similar in composition to modern pine sap are consistent with other published studies of Egyptian embalming materials (Lucas 1934; Proefke and Rinehart 1992; Koller et al. 2005). Written sources (Herodotus, Diodorus, Pliny the Elder) repeatedly mention the use of cedar oil in embalming, although Aufderheide (2003) argues that widespread use of cedar was unlikely on the basis that cedar wood produces little resin, pointing out that pine species are a much more abundant source. Proefke and Rinehart (1992) cite five species of coniferous trees native to the Levant, from whence resin was traded to Egypt. A small number of examples are known of resin being poured into cranial cavities multiple times (Hoffman and Hudgins 2002). The most well-known mummy to exhibit such a double pour is that of Tutankhamun, with a double meniscus as in the Boscastle skull, although in Tutankhamun's case, one pour seems to have taken place with the mummy positioned upside down (Boyer et al. 2003). It was not possible to distinguish from the $\mathrm{CT}$ data obtained whether the two pours were composed of differing substances, although this question may be resolved in the future with improvements in scanning technology.

As part of an Egyptian mummy purported to be a Medieval 'relic', the Boscastle skull has parallels with a small quantity of human bone recently analysed by a French multidisciplinary team (Charlier et al. 2010a, b). These remains comprised three small bone fragments plus a scrap of textile, sealed within a glass bottle. The bottle had been curated in a church in Chinon, central France, and were purported to be "remains found under the pyre of Joan of Arc" (1412-1431). Application of a range of techniques to the bottle's contents revealed two of the bone fragments 
to be human, with the third being part of a cat's femur. The bones showed no signs of cremation, whilst a vitreous black substance with which they were coated was found to resemble samples of resin coating from an Egyptian mummy using FTIR spectroscopy. The textile closely resembled gauze of the kind used in Egyptian mummification, whilst radiocarbon dating of the bones produced results ranging from 695 to $234 \mathrm{cal} \mathrm{BC}$. Typological study of the bottle, coupled with analysis of handwriting on its lid, led to the conclusion that this 'relic' was a forgery produced during the nineteenth century. In this respect, the Chinon 'relics' would appear to have parallels with the Boscastle skull as parts of an Egyptian mummy being passed off as European saintly relics. Returning to the points made regarding the tarring of severed heads (etc.) and stories such as that of the four martyrs' heads found in pewter boxes in the cellar in Blackfriars (Strype 1720), it seems likely that such accounts were probably the inspiration for the story given for the Boscastle skull's origin rather than the skull being a genuine example of a similar survival.

The skull is perhaps most likely to have been brought to Britain during the nineteenth century by a wealthy individual that had travelled to Egypt. However, other possibilities should also be considered. Mummies were certainly entering Europe in significant numbers from the early eighteenth century, by which time they had become valued as curiosities. Such imports may at times have changed hands repeatedly, and the Boscastle skull need not have been brought direct to Britain from Egypt. Prior to this, however, an earlier craze had brought numerous mummies and mummy parts into Europe for use in medicines from at least as early as the fourteenth century (Ikram and Dodson 1998; Lynnerup 2007). Consequently, there is no reason why the association between the skull and the oak box should not be centuries old rather than a recent concoction of the nineteenth or twentieth century.

The box is possibly the most enigmatic aspect of the Boscastle museum accession. At present, the box remains undated, although if it is assumed that it is not a later forgery, the carved images would tend to suggest a date some time during the Early Modern period. Of particular note are the puffed out, multiply slashed sleeves visible on all four panels showing human figures. Such a style would date the figures to the sixteenth or the seventeenth century, although other details are rendered ambiguous by the naive style of the carving, for example it is unclear whether the figures on the lid (Fig. 2d) are wearing some form of head gear or if the respective forms represent hairstyles or wigs. Considerable potential remains for further analyses of both box and skull, with DNA and stable isotope analysis standing out as obvious possibilities regarding the latter, although the range of possible further investigations will doubtless increase in years to come.
It is not unusual within palaeoradiography to discover anecdotal histories regarding particular remains to be based on at best 'marginal truths' or simply to be complete fabrications (Conlogue et al. 2008). Conversely, as in the cases of Cromwell and Henri IV, where human remains have been curated in private hands for long periods, sometimes dramatic stories or illustrious identities attached to them and maintained through oral transmission are found to be true. In the case of examples such as the 'Jeanne D'Arc' relics from Chinon (Charlier et al. 2010a, b) and the Boscastle head, such attributions can be demonstrated through scientific analysis to be false. Without such verification, we would therefore argue that such claims of dramatic or famous identities for unusual human remains in museum collections should be regarded with a degree of scepticism. We would concur with other recent researchers in arguing that such analyses should be conducted using as many lines of evidence as possible.

Lastly, however, perhaps a more important point to emerge from the analyses presented here is that unprovenanced human remains within museum collections need not be seen essentially as 'lost' material about which nothing useful can be learned. The range and precision of analytical techniques that are widely available to researchers has expanded dramatically in recent years, and this trajectory will doubtless continue. In the future, we would argue that there will come a time when no human remains need be regarded as unprovenanced. In light of this point, curating institutions arguably have a responsibility to continue to care for such material and cannot use the issue of inadequate provenance as a pretext for the reburial or otherwise disposal of the remains of past peoples.

Acknowledgements We are very grateful to Graham King, Hannah Fox, Kerriann and colleagues at the Museum of Witchcraft, Boscastle, Cornwall, UK, for permitting the loan of the cranium and box for analysis. We would like to thank the CT/MRI Department, Radiology, Poole Hospital NHS Foundation Trust, for the use of noninvasive imaging facilities. Thanks are due to Alex Otto and Damian Evans for assisting with photography. The radiocarbon date was obtained at the University of Waikato Radiocarbon Dating Laboratory.We are also grateful to Richard Harris for kindly examining and sharing his opinions on the box. Finally, we are particularly indebted to Andrew Nelson and Andrew Wade of the University of Western Ontario for taking the time to provide commentary on our CT images and for kindly providing CT scan data of their own for comparison in addition to commenting on an earlier version of this manuscript.

\section{Image permissions}

1. The image of the head of St. Oliver Plunkett (Fig. 3a), by kind permission of Mr. Tommy Burns and Father James Carroll, St. Peter's Parish Drogheda

2. The image of the Wilkinson Head (Fig. 3b) originally appeared in Pearson and Morant (1934), by permission of the Oxford University Press 3. The image of the head identified as that of Henri IV of France (Fig. 3c) by kind permission of Dr. Phillippe Charlier, reproduced from British Medical Journal, Charlier et al. 2010a, with permission from BMJ Publishing Group Ltd.

4. The two images in Fig. 6 by kind permission of Dr. Andrew Wade and Dr. Andrew Nelson 


\section{References}

Abbott G (2000) Severed heads: British beheadings through the ages. André Deutsch, London

Acsádi G, Nemeskéri J (1970) History of human life span and mortality. Akademiai Kiado, Budapest

Aufderheide AC (2003) The scientific study of mummies. Cambridge Press, Cambridge

Benson GG, Hemingway SR, Leach FN (1979) The analysis of the wrappings of mummy 1770. In: David R (ed) The Manchester Museum Mummy Project. Maney and Son, Leeds, pp 119-136

Boyer RS, Rodin EA, Grey TC, Connolly RC (2003) The skull and cervical spine radiographs of Tutankhamen: a critical appraisal. Am J Neuroradiol 24:1142-1147

Bronk Ramsey C (2010) OxCal program v.4.1.7, Oxford

Brothwell DR (1994) Digging up bones. Oxford University Press, Oxford

Buikstra J, Ubelaker D (1994) Standards for data collection from human skeletal remains. Arkansas Archaeological Survey, Arkansas

Centerwall BS (1997) The name of the green man. Folklore 108:25-33

Charlier P, Huynh-Charlier I, Poupon J, Keyser C, Lancelot E, Favier D, Vignal J, Sorel P, Chaillot P, Boano R, Grilletto R, Delacourte S, Duriez J, Loublier Y, Campos P, Willerslev E, Gilbert MTP, Eisenberg L, Ludes B, Lorin de la Grandmaison G (2010a) Multidisciplinary medical identification of a French king's head (Henri IV). Br Med J 341:c6805

Charlier P, Poupon J, Eb A, De Mazancourt P, Gilbert T, HuynhCharlier I, Loublier Y, Verhille AM, Moulheirat C, Patou-Mathis M, Robbiola L, Montagut R, Masson F, Etcheberry A, Brun L, Willerslev E, Lorin de la Grandmaison G, Durigon M (2010b) The 'relics of Joan of Arc': a forensic multidisciplinary analysis. Forensic Sci Int 194:e9-e15

Conlogue G, Beckett R, Bailey Y, Posh J, Henderson D, Double G, King T (2008) Paleoimaging: the use of radiography, magnetic resonance, and endoscopy to examine mummified remains. $\mathrm{J}$ Radiol Nurs 27:5-13

Fletcher J (2002) Ancient Egyptian hair and wigs. The Ostracon 13:2-8 Gerloni A, Cavalli F, Costantinides F, Costantinides F, Bonetti S, Paganelli C (2009) Dental status of three Egyptian mummies: radiological investigation by multislice computerized tomography. Oral Surg Oral Med Oral Pathol Oral Radiol Endod 107: e58-e64

Gill GW (1998) Craniofacial criteria in the skeletal attribution of race. In: Reichs K (ed) Forensic osteology. Charles C, Thomas, Springfield, pp 293-314

Gove HE, Mattingly SJ, David AR, Garza-Valdes LA (1997) A problematic source of organic contamination of linen. Nuclear Instruments and Methods in Physics Research B 123:504-507

Herodotus. Histories. (translated by Rawlinson G) (1996) Wordsworth Classics, Ware

Hillson S (1996) Dental anthropology. Cambridge University Press, Cambridge

Hinks R (1928) A portrait of a Ptolemaic queen. J Hell Stud 48:239_ 242

Hoffman H, Hudgins PA (2002) Head and skull base features of nine Egyptian mummies: evaluation with high-resolution CT and reformation techniques. Am J Roentgenol 178:1367-1376

Hughes SW (1996) Three-dimensional reconstruction of an ancient Egyptian mummy. In: Imaging the past. Electronic imaging and computer graphics in museums and archaeology. British Museum Occasional Paper, 114. The British Museum, London, pp 211-225

Hughes S, Wright R, Barry M (2005) Virtual reconstruction and morphological analysis of the cranium of an ancient Egyptian mummy. Australas Phys Eng Sci Med 28:122-127
Ikram S, Dodson A (1998) The mummy in ancient Egypt: equipping the dead for eternity. Thames and Hudson, London

Jansen RL, Poulus M, Taconis W, Stoker J (2002) High resolution spiral computed tomography with multiplanar reformatting, 3D surface and volume rendering: a non-destructive method to visualize ancient Egyptian mummification techniques. Comput Med Imaging Graph 26:211-216

Keita SOY (1993) Studies and comments on ancient Egyptian biological relationships. Hist Afr 20:129-154

Kieser J, Dennison J, Anson D, Doyle T, Laing R (2004) Spiral computed tomographic study of a pre-Ptolemaic Egyptian mummy. Anthropol Sci 112:91-96

Kilfeather H (2002) Oliver Plunkett's head. Textual Practice 16:229 248

Knüsel CJ, Batt CM, Cook G, Montgomery J, Müldner G, Ogden AR, Palmer C, Stern B, Todd J, Wilson S (2010) The identity of the St. Bees Lady, Cumbria: an osteobiographical approach. Mediev Archaeol 54:271-311

Koller J, Baumer U, Kaup Y, Weser U (2005) Herodotus' and Pliny's embalming materials identified on ancient Egyptian mummies. Archaeometry 47:609-628

L'Engle S (2002) Justice in the margins: punishment in medieval Toulouse. Viator 33:133-165

Lucas A (1934) Ancient Egyptian materials and industries. Edward Arnold, London

Lynnerup N (2007) Mummies. Yearb Phys Anthropol 50:162-190

Marx M, D'Auria Haney S (1986) CT examination of 11 Egyptian mummies. Radiographics 6:321-330

Miles AEW (2001) The Miles method of assessing age from tooth wear revisited. J Archaeol Sci 28:973-982

Nelson AJ, Conlogue G, Beckett R, Posh J, Chem R, Wright E, Rogers J (2007) Multimodal analyses of variability in transnasal craniotomy lesions in egyptian mummies. Poster presented at the 34th Annual Meeting of the Palaeopathology Association, Philadelphia

BBC News Online (2011) Severed head of patron saint of genital disease on sale. http://www.bbc.co.uk/news/uk-northern-ireland13522546. Accessed 31 May 2011

O'Connor S, Ali E, Al-Sabah S, Anwar D, Bergström E, Brown KA, Buckberry J, Buckley S, Collins M, Denton J, Dorling KM, Dowle A, Duffey P, Edwards H, Correia Faria E, Gardner P, Gledhill A, Heaton K, Heron C, Janaway R, Keely B, King D, Masinton A, Penkman K, Petzold A, Pickering M, Rumsby M, Schutkowski H, Shackleton K, Thomas J, Thomas-Oates J, Usai M, Wilson A, O'Connor T (2011) Exceptional preservation of a prehistoric human brain from Heslington, Yorkshire, UK. J Archaeol Sci 38:1641-1654. doi:10.1016/j.jas.2011.02.030

Pearson K, Morant GM (1934) The Wilkinson head of Oliver Cromwell and its relationship to busts, masks and painted portraits. Biometrika 26:1-116

Proefke ML, Rinehart KL (1992) Analysis of an Egyptian mummy resin by mass spectrometry. J Am Soc Mass Spectrom 3:582-589

Raglan (1939) The 'green man' in church architecture. Folklore 50:45-57

Ribechini E, Modugno F, Baraldi C, baraldi P, Colombini MP (2007) An integrated approach for characterizing an organic residue from an archaeological glass bottle recovered in Pompeii (Naples, Italy). Talanta 74:555-561

Rozkovcová E, Marková M, Dolejsí J (1999) Studies on agenesis of third molars amongst populations of different origin. Sborník Lékařský 100:71-84

Ruffer A (1920) Study of abnormalities and pathology of ancient Egyptian teeth. Am J Phys Anthropol 3:335-382

Rühli FR, von Waldburg H, Nielles-Vallespin S, Böni T, Speier P (2007) Clinical magnetic resonance imaging of ancient dry 
human mummies without rehydration. JAMA 298:26182620

Stern B, Heron C, Tellefsen T, Serpico M (2008) New investigations into the Uluburun resin cargo. J Archaeol Sci 35:2188-2203

Strype J (1720) A survey of the cities of London and Westminster. Humanities Research Online: Electronic edition, version 1.0. http://www.hrionline.ac.uk/strype/. Accessed 30 December 2010
Tarlow S (2008) The extraordinary history of Oliver Cromwell's head. In: Borić D, Robb J (eds) Past bodies: body centred research in archaeology. Oxbow, Oxford, pp 69-78

Wade AD, Nelson AJ (2011) Heart treatment in ancient Egyptian 100 mummification. Am J of Phys Anthropol S52

Wilson AS, Dixon RA, Dodson HI, Janaway RC, Pollard AM, Stern B, Tobin DJ (2001) Yesterday's hair-human hair in archaeology. Biologist 48:213-217 